\title{
PEMAHAMAN WANITA ISLAM KG. MANJOI, PERAK TERHADAP HUKUM JUAL BELI BARANG PERHIASAN DARIPADA EMAS SECARA ANSURAN
}

\section{Understanding the Muslim Women Community of Kg. Manjoi, Perak Concerning the Law of Buying and Selling Jewellary by Instalment}

\author{
Farhatun Atmam Jamaluddin * \\ Shamsiah Mohamad **
}

\begin{abstract}
Community Kg. Manjoi mostly involved with the women in the community of Kg. Manjoi are mostly involved in buying and selling jewellery. Sometimes they buy it in instalments, cash, trade in, and so on. This study aims to understand the law of buying and selling gold jewellery from the Islamic perspective. In addition, this study aims to determine the level of understanding of Muslim women in Kg. Manjoi towards purchasing gold jewellery by instalments. Data were collected using the documentation and survey method. The data for the survey method in the current study were collected by means of a questionnaire administered on a sample of 80 respondents in an attempt to identify the relationship between the understanding of Muslim women in Kg. Manjoi towards purchasing gold jewellery by instalments and
\end{abstract}

* Calon Sarjana Syariah, Jabatan Fiqh \& Usul, Akademi Pengajian Islam, Universiti Malaya, Kuala Lumpur, farhatunatmam@yahoo. com.

** Prof. Madya, Jabatan Fiqh \& Usul, Akademi Pengajian Islam, Universiti Malaya, Kuala Lumpur, shamsiahm@um.edu.my. 
stream education and level of education. Data were analysed by using SPSS 20.0. This study finds that the understanding of Muslim women in Kg. Manjoi towards purchasing gold jewellery by instalments is at a low level. Most of them are little concerned about the law relating to selling and purchasing gold jewellery.

Keyword: Instalments, Gold Jewellery, Buying and Selling Gold

\section{PENGENALAN}

Emas merupakan sejenis logam berwarna kuning yang mahal harganya. Pada kebiasaannya ia dijadikan perhiasan seperti rantai, cincin dan sebagainya. ${ }^{1}$ Islam telah mengkategorikan emas dalam salah satu daripada barangan ribawi yang perlu diberi perhatian bagi mengelakkan seseorang terjerumus ke dalam sebarang transaksi yang mengandungi unsur riba. Rasulullah SAW telah menerangkan cara transaksi yang melibatkan barangan ribawi secara khusus. ${ }^{2}$ Penerangan ini adalah bertujuan untuk mengelakkan orang ramai daripada mengambil kesempatan dengan melakukan manipulasi demi mendapatkan keuntungan yang berlipat kali ganda. Ini adalah disebabkan kedudukan emas mempunyai nilaian tinggi di mata manusia.

Di zaman moden ini, emas yang dicanai sehingga membentuk barangan perhiasan telah menarik minat kebanyakan wanita untuk mendapatkannya baik bagi golongan yang berkemampuan atau sebaliknya. Mereka menjadikannya sebagai barang perhiasan. Bagi mereka yang berkemampuan, mereka kebiasaannya membeli barang perhiasan tersebut secara tunai dan ini tidak membebankan mereka. Tetapi, bagi mereka yang kurang berkemampuan, mereka kebiasaannya membelinya secara bertangguh dengan membuat bayaran secara ansuran.

Noresah Baharom et al., Kamus Dewan Edisi Keempat (Kuala Lumpur: Dewan Bahasa Dan Pustaka, 2007), 386.

2 Muḥammad bin Futūḥ al-Ḥumaydī, al-Jam ' Bayn al-Șahīhayn, Bāb Muttafaq 'Alayh Musnad Abī Sa ‘ìd (al-Su'ūdiyyah: Dār Ibn Ḥazm, t. t.), 2:426. 


\section{DEFINISI JUAL BELI DAN BARANG PERHIASAN}

Jual beli dalam Bahasa Arab disebut bay ' yang membawa dua makna iaitu jual dan beli. ${ }^{3}$ Dari sudut bahasa ia bermaksud pertukaran sesuatu dengan sesuatu. ${ }^{4}$ Secara terminologi, walaupun para fuqaha Ḥanafiyyah, ${ }^{5}$ Mālikiyyah, ${ }^{6}$ Shāfi idyyah $^{7}$ dan Hanābilah ${ }^{8}$ memberikan definisi yang berbeza dari segi 'ibārah tetapi tujuan dan kandungannya adalah sama. Melalui definisi-definisi tersebut, dapat disimpulkan bahawa jual beli adalah satu proses pertukaran suatu harta dengan harta yang lain yang membawa kepada pertukaran hak milik.

Manakala barang perhiasan atau lebih dikenali dengan barang kemas menurut Kamus Dewan Edisi Keempat adalah barangan yang tinggi nilainya seperti barang perhiasan daripada emas, permata dan sebagainya. ${ }^{9}$

Memandangkan istilah barang kemas merangkumi semua barang perhiasan baik yang dibuat daripada emas, perak dan sebagainya, maka dalam penulisan ini istilah barang perhiasan daripada emas akan digunakan kerana kajian ini hanya melibatkan barang perhiasan yang diperbuat daripada emas sahaja.

3 Muhammad bin Mukarram Ibn Manẓūr, Lisān al- 'Arab (al-Qāhirah: Dār al-Ma' ārif, 1119), 4:401.

4 Maḥmūd 'Abd al-Raḥmān al-Mun'im, Mu ‘jam al-Muștalahāt wa alAlfāz al-Fiqhiyyah (al-Qāhirah: Dār al-Faḍilah, 1999), 1:395.

5 Muhammad Amīn Ibn 'Ābidīn, Radd al-Muhtār 'alā al-Durr alMukhtār Sharh Tanwīr al-Abṣār (al-Riyāḍ: Dār 'Ālim al-Kutub, 2003), 7:13. Lihat juga 'Alā' al-Dīn Abū Bakr al-Kāsān̄̄, Badā'i' al-Ṣanā' ' ' fì Tartīb al-Sharā' 'i' (Bayrūt: Dār al-Kutub al-'Ilmiyyah, 1986), 5:133.

6 Muhammad 'Urfah al-Dusūqī, Hāāshiyah al-Dusūqī 'alā al-Sharh al-Kabīr (al-Mișr: Maktabah 'Isā al-Bābī al-Ḥalabī wa Shurakah, 1809), 3:2.

7 Aḥmad bin Aḥmad al-Qalyūbī, Hāshiyah Qalyūbō 'alā Kanz alRāghib (Bayrūt: Dār al-Kutub al-'Ilmiyyah, 1998), 243. Lihat juga Yahyā̄ bin Sharīf Abū Zakariyyā al-Nawawī, al-Majmū' Sharh alMuhadhdhab (al-Su'ūdiyyah: Maktabah al-Irshād, 1970), 9:149.

8 Ibn Qudāmah, Abū Muḥammad 'Abd Allah bin Aḥmad, al-Mughn̄̄ (al-Riyāḍ: Dār A’lām al-Kutub, 1985), 6:5.

$9 \quad$ Noresah Baharom et al., Kamus Dewan, 728. 


\section{HUKUM JUAL BELI BARANG PERHIASAN DARIPADA EMAS SECARA ANSURAN MENGGUNAKAN WANG KERTAS}

Dalam dunia moden hari ini, transaksi jual beli akan melibatkan penggunaan wang kertas sebagai alat pertukaran. Oleh itu, tulisan ini akan menerangkan pandangan fuqaha tentang kedudukan wang kertas sebagai harta ribawī sebelum membahaskan tentang hukum jual beli barang perhiasan daripada emas secara ansuran.

\section{Perbahasan Fuqaha Mengenai Kedudukan Wang Kertas Sebagai Harta Ribawī}

Fuqaha berbeza pendapat dalam menentukan sama ada wang kertas termasuk dalam kategori barangan ribawi atau sebaliknya. Terdapat dua pandangan fuqaha berhubung masalah ini.

Pandangan Pertama: Wang kertas adalah barang ribawī meskipun tidak dibuat daripada emas dan perak. Ia merupakan pendapat mazhab Maliki, ${ }^{10}$ mazhab Shafii ${ }^{11}$ dan Ibn Taymiyyah. ${ }^{12}$ Mereka berpendapat bahawa riba akan terjadi pada semua jenis barang yang dijadikan sebagai matawang berdasarkan kepada kaedah alqiyās. Ini kerana kesemua barang-barang yang dijadikan sebagai matawang mempunyai 'illah yang sama. Imam Mālik mengatakan bahawa jikalau manusia menerima kulit binatang yang dibentuk sebagai matawang, nescaya beliau akan menerimanya. ${ }^{13}$ Ini menunjukkan pendirian Imam Malik boleh diadaptasikan dengan penggunaan wang kertas pada masa kini.

Menurut keputusan Majma' al-Fiqh al-Islāmī, wang kertas mempunyai 'illah yang bersifat matawang (thamaniyyah). Oleh

10 Ibn Anas, Mālik, al-Mudawwanah al-Kubrā (Bayrūt: Dār al-Kutub al-'Ilmiyyah, 1902), 8:396.

11 Muhammad bin Idrīs al-Shāfi‘'̄a, al-Umm (al-Manșūrah: Dār alWafā', 2001), 4:257.

12 Abū al-'Abbās Aḥmad bin 'Abd al-Halīm al-Harranī Ibn Taymiyyah, Majmū' al-Fatāwā (al-Manșūrah: Dār al-Wafā', 2005), 29:257258.

13 Ibn Anas, al-Mudawwanah al-Kubrā, 396. Lihat juga Zaharuddin Abd. Rahman, Riba Dan Isu Kewangan Semasa (Kuala Lumpur: Telaga Biru, 2010), 70. 
itu, hukum mengenainya tertakluk seperti hukum pada emas dan perak iaitu berkaitan hukum riba, kewajipan zakat, jual beli secara salam dan lain-lain hukum emas dan perak. ${ }^{14}$ Ini bertepatan dengan pandangan 'Umar. Di waktu pemerintahannya, 'Umar mempunyai hasrat untuk menjadikan kulit kerbau sebagai matawang, tetapi beliau membatalkan hasratnya kerana dikhuatiri akan berlaku pinjam-meminjam kerbau lalu ia akan membawa kepada riba. ${ }^{15}$ Ini bererti, 'Umar melihat apa sahaja yang dijadikan matawang walaupun selain emas dan perak, hukum riba masih tetap ada padanya. ${ }^{16}$

Pandangan kedua: Wang kertas tidak dikategorikan sebagai barangan ribawī. Ini merupakan pendapat daripada Imam Shafii, ${ }^{17}$ al-Māwardī ${ }^{18}$ dan al-Qaraḍāwī. ${ }^{19}$ Mereka berpandangan bahawa emas dan perak mempunyai 'illah yang bersifat terbatas ('illah qāssirah) dan ia merujuk kepada emas dan perak sahaja. Disamping itu, mereka turut menghadkan matawang Shariah hanya kepada emas dan perak. ${ }^{20}$ Meskipun wang kertas digunakan, namun ia tetap bukan daripada emas dan perak. ${ }^{21}$

Hujah yang dikemukakan olehpandangan pertamalebihberasas. Ini kerana, 'illah yang terdapat pada wang kertas sama seperti 'illah yang terdapat pada matawang emas dan perak walaupun ia hanya berdasarkan pada kehendak, keyakinan dan kepercayaan orang ramai terhadap nilainya. Di samping itu, faktor cengkaman

14 Majma' al-Fiqh al-Islāmī al-Duwalī, http://www.fiqhacademy.org. sa/qrarat/3-9.htm, diakses pada 30 April 2012 .

15 Abū 'Abbās Aḥmad bin Yaḥyā al-Balādharī, Futūḥ al-Buldān (Bayrūt: Mu'assasah al-Ma'ārif, 1987), 406. Lihat juga Zaharuddin Abd. Rahman, Riba Dan Isu Kewangan Semasa, 70.

16 Rafīq Yūnus al-Miṣrī, al-Jāmi ${ }^{`}$ fì Ușūl al-Ribā (Damshiq: Dār alQalam, 2001), 114.

17 Al-Shāfi‘̄i, al-Umm, 257.

18 Abū 'Abd Allāh Badr al-Dīn al-Zarkashī, al-Ma 'thūr fì al-Qawā'id alFiqhiyyah (Kuwayt: Wizārah al-Awqāf wa al-Shu'ūn al-Islāmiyyah, 1985), 3:244.

19 Yūsuf al-Qaraḍāwī, Fiqh al-Zakāh (Bayrūt: Mu'assasah al-Risālah, 1973), 1:271. Lihat juga Yūsuf al-Qaraḍāwī, Dirāsah fì Maqāṣid alSharī'ah (al-Qāhirah: Dār al-Shurūq, 2008), 67.

20 Al-Qaraḍ̄̄wī, Dirāsah fì Maqāșid al-Sharī'ah, 67.

21 Al-Zarkashī, al-Ma'thūr fī al-Qawā'id al-Fiqhiyyah, 244. 
ekonomi dunia berada di tangan orang bukan Islam dan keperluan mendesak kepada penggunaan matawang kertas. Ini disebabkan ketiadaan alternatif di hadapan mata seperti matawang dinar emas dan sebagainya. ${ }^{22}$ Majlis Fiqh Antarabangsa telah bersepakat membenarkan penggunaannya namun dengan syarat ia mestilah mengikuti displin dan syarat yang sama dengan hukum atas emas dan perak. Kesimpulannya, wang kertas sama seperti emas dan perak dan Islam mengiktiraf penggunaannya dalam urusan harian meskipun tidak terdapat dalam al-Quran mahupun Hadis.

\section{Pandangan Fuqaha Tentang Hukum Jual Beli Barang Perhiasan Daripada Emas Secara Ansuran}

Dalam persoalan jual beli barang perhiasan daripada emas secara ansuran, para fuqaha berselisih pendapat mengenainya. Perselisihan ini berpunca daripada pemahaman terhadap hadishadis berkenaan dengan kedudukan sifat barang perhiasan yang diperbuat daripada emas. Ini boleh dilihat apabila para fuqaha berbeza pendapat dalam menentukan sama ada barang perhiasan yang diperbuat daripada emas termasuk dalam barangan ribawi atau sebaliknya. Terdapat dua pandangan berkenaan dengan masalah ini sebagaimana berikut:

Pandangan pertama: Jual beli barang perhiasan emas secara ansuran adalah haram. Ini kerana pandangan ini berpendapat bahawa sebarang bentuk emas sama ada berbentuk ketulan, ditempa, atau disadur, ia adalah sama seperti emas yang belum melalui proses berkenaan. Pandangan ini didokongi oleh mazhab Hanafi, ${ }^{23}$ mazhab Maliki, ${ }^{24}$ mazhab Shafii ${ }^{25}$ dan mazhab Hanbali ${ }^{26}$. Malah, menurut sebahagian fuqaha seperti Ibn Mundhir, ${ }^{27} \mathrm{Ibn}$ al-

\footnotetext{
22 Zaharuddin Abd. Rahman, Riba Dan Isu Kewangan Semasa, 70.

23 Muḥammad bin Aḥmad bin Abū Sahl al-Sarakhsī, al-Mabsūt (Bayrūt: Dār al-Ma'rifah, 1989), 14:4.

24 Ibn Rushd al-Qurțub̄i, al-Bāyān wa al-Taḥ̣̂̂ll (Bayrūt: Dār al-Gharbī al-Islāmi, 1988), 6:444.

25 Al-Shafi' $\overline{1}$, al- $\bar{U} m m, 32$.

26 Ibn Qudāmah, Abū Muḥammad 'Abd Allah bin Aḥmad, al-Mughñ̄ (Bayrūt: Dār al-Fikr, 1985), 6:60.

27 Ibn Mundhir, Abū Bakr Muḥammad bin Ibrāhīm, Ijmā' (Ajmān: Dār al-Furqān, 1999), 33.
} 
Barr, ${ }^{28}$ dan Ibn Hubayrah, ${ }^{29}$ mereka mengatakan, telah berlaku ijmak bahawa hukum jual beli barang perhiasan secara ansuran adalah tidak sah. Mereka merujuk kepada hadis Nabi SAW yang diriwayatkan oleh 'Ubādah bin al-Șāmit, daripada Rasulullah SAW:

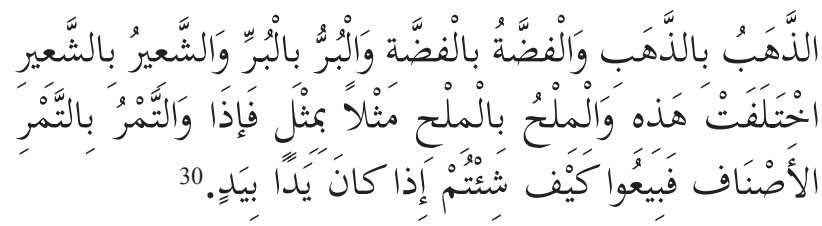

Maksudnya: "Emas dengan emas (ditukar atau diniagakan), perak dengan perak, gandum dengan gandum, barli dengan barli, tamar dengan tamar, garam dengan garam mestilah sama timbangan dan sukatan, dan sekiranya berlainan kategori ini, maka berjual belilah kamu sebagaimana yang kamu sukai selagi ia dilakukan secara tunai"

Pendokong kepada pandangan pertama ini juga menyangkal hujah pandangan kedua yang mengatakan keharusan jual beli barang perhiasan daripada emas secara ansuran. Mereka mengatakan bahawa meskipun emas tersebut telah dibentuk, namun sifat emas dan perak yang wujud dalam barang kemas tersebut masih tetap kekal. ${ }^{31}$ Hasil pertukangan yang berlaku ke atas barang perhiasan tersebut tidak memberi sebarang impak kepada hukum emas yang asal. ${ }^{32}$

28 Abū 'Umar Yūsuf bin 'Abd Allah al-Barr, Istidhkār (Bayrūt: Dār Qutaybah, 1993), 19:192.

29 Yahyā bin Muhammad Ibn Hubayrah, Ifșāh 'an Ma'ānī al-Ṣahāh (al-Riyāụ: Dār al-Wațan, 1996), 1:212.

30 Muslim, Abū al-Ḥusayn Muslim, Șaḥ̄h Muslim, Kitāb Musāqāh, Bāb al-Nahyī 'an Bay' al-Warīq, no. hadith 1587 (al-Riyāḍ: Bayt al-Afkār al-Dawliyyah, 1998), 647.

31 Al-Sarakhsī, al-Mabsūt, 4.

32 Shams al-Dīn Muhammad bin Aḥmad al-Sharbīn̄̄, Mughnī alMuhtāj ilā Ma 'rifah Ma 'ān̄̄ Alfāz al-Minhāj (Bayrūt: Dār al-Fikr, 1978), 2:25. 
Pandangan pertama ini turut dipersetujui oleh ulama kontemporari seperti Uthaymīn. ${ }^{33}$

Secara umumnya, pandangan golongan ini adalah berdasarkan kepada zahir hadis yang mengharamkan jual beli barang ribawi kecuali dengan persamaan timbangan dan pertukaran, berlaku secara serta merta (tanāqud) dalam majlis akad.

Pandangan kedua: Jual beli barang kemas secara ansuran adalah diharuskan. Pandangan ini didokongi oleh Ibn Taymiyyah, Ibn Qayyim, dan Ibn Rushd. Pandangan ini juga disokong oleh beberapa ulama kontemporari seperti al-Qaraḍāwi.. ${ }^{34}$

Pandangan ini dicetuskan oleh Mu'āwiyah Ibn Ab̄̄ Sufyān. Berdasarkan kitab Muwaț̣ā', Imam Mālik ${ }^{35}$ telah meriwayatkan bahawa:

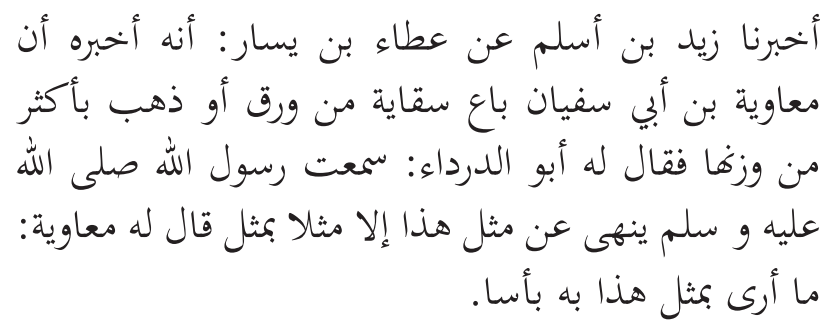

Maksudnya: "Telah diceritakan oleh Zayd bin Aslam daripada Ațā' Ibn Yasār bahawa Mu'āwiyah Ibn Abì Sufyan telah menjual cairan emas atau syiling emas dengan timbangan yang lebih banyak. Abū al-Dardā' kemudian menegurnya dengan berkata: "Aku mendengar Rasulullah SAW melarang jual beli jenis ini kecuali dengan persamaan antara keduaduanya". Lalu Mu'āwiyah menjawab: "Aku melihat dalam isu ini tidak terdapat masalah”.

33 Muhammad bin Șālih al-'Uthaymīn et al., Fatāwā al-Buyū' wa alMu'āmalāt al-Màliyyah (Iskandariyyah: Dār al-Imān, 2004), 104.

34 Al-Qaraḍāwī, Dirāsah fì Maqāṣid al-Sharī'ah, 67.

35 Mālik Ibn Anas, al-Muwatțā', Kitāb al-Buyū' (t. t. p.: Majmū'ah alFurqān al-Tijāriyyah, 2003), 3:391. 
Abū al-Dardā' dan Ibn 'Umar menolak pandangan Mu'āwiyah ini kerana bagi mereka ia bersalahan dengan hadis-hadis Nabi SAW.

Sebenarnya, Ibn Taymiyyah sependapat dengan jumhur melalui bukunya Majmū' al-Fatāwā, namun beliau mengubah pendapat dalam bukunya Tafsìr Ayāt Ashkalāt. ${ }^{36}$ Dalam tafsir ini, beliau menyebut jual beli barangan tempatan yang terdiri daripada emas dan perak adalah dibolehkan tanpa disyaratkan wujud persamaan dan menjadikan lebihan daripadanya sebagai balasan atau upah kepada pertukangan tersebut sama ada jual beli secara tunai atau tangguh, asalkan tidak dijadikan sebagai harga bagi barangan. ${ }^{37}$ Pendapat Ibn Taymiyyah pada keharusan jual beli barang kemas ini disokong oleh Ibn Qayyim. ${ }^{38}$

Menurut Ibn Rushd ${ }^{39}$ dan Ibn Qayyim ${ }^{40}$ perhiasan emas telah terkeluar daripada kategori emas tulen. Justeru harus menjual dan membelinya secara ansuran. Ibn Muflih al-Hanbalī menjelaskan bahawa emas telah terkeluar daripada sifat asal disebabkan pertukangan atau pembuatan $(a l-\sin \bar{a} ' a h){ }^{41}$

Ibn Taymiyyah menyatakan barang perhiasan emas dan perak sudah terkeluar dari kategori emas dan perak kerana 'illah riba pada emas dan perak iaitu matawang sudah tidak wujud. Ini kerana apabila emas dan perak tersebut telah menjadi barang perhiasan hasil daripada pertukangan atau tempaan, maka ia sama seperti barangan perniagaan ('urü dijārah) yang lain. Dengan ini barangan perhiasan tersebut boleh dijual secara berlebih kurang

36 Aḥmad bin 'Abd al-Ḥalīm al-Ḥarrān̄̄ Abū al- 'Abbās Ibn Taymiyyah, al-Akhbār al-'Ilmiyyah al-Ikhtiyārāt al-Fiqhiyyah (t. t. p.: Dār 'Āṣimah, 1950), 188.

37 Aḥmad bin 'Abd al-Ḥalīm al-Ḥarrān̄i Abū al-'Abbās Ibn Taymiyyah, Tafsīr Āyāt Ashkalāt (al-Riyāḍ: Maktabah al-Rushd, 1996), 1:622632.

38 Ibn al-Qayyim, Shams al-Dīn Abū 'Abd Allah. I'lām al-Muwaqqi'īn 'an Rabb al-'Ālamīn (al-Su'ūdiyyah: Dār Ibn Jawzy, 2002), 2:625.

39 Ibn Rushd, Bidāyah al-Mujtahid wa Nihāyah al-Muqtașid (Bayrūt: Dār al-Ma'rifah, 1982), 2:195-196 .

40 Ibn al-Qayyim, I'lām al-Muwaqqi 'ìn, 405-4011.

41 Ibn Mufliḥ, Isḥāq Burhān al-Dīn Ibrāhīm, Mubdi ' Sharh al-Muqni ‘ (Bayrūt: Dār al-Kutub 'Ilmiyyah, 1997), 4:128. 
tanpa sama dari segi timbangan dan boleh dilakukan secara ansuran. ${ }^{42}$ Pandangan ini dikuatkan lagi dengan hujah lain iaitu emas dan perak merupakan matawang yang diwajibkan zakat. Namun, apabila kedua-duanya telah dibentuk menjadi barangan perhiasan, maka ia tidak lagi diwajibkan zakat. Justeru, perhiasan adalah barangan yang boleh dijual beli seperti biasa dan tidak tertakluk dengan syarat jual beli emas. ${ }^{43}$

Menurut Ibn Qayyim, masyarakat pada zaman Nabi SAW sering menggunakan barangan perhiasan. Terdapat pencanaipencanai emas di Madinah dan mereka sering melakukan jual beli barang perhiasan yang diperbuat daripada emas atau perak. Apa yang jelas, mereka semua menjual barangan tersebut secara berbeza pada kuantiti timbangan (tafädul). Sebaliknya sesiapa yang menjualnya dengan timbangan yang sama, akan dianggap kurang cerdik dan boleh ditegah tindak tanduknya. ${ }^{44}$

Imam al-Nawawī yang merupakan fuqaha muta'akhkhirīn dalam mazhab Shafii telah mengharuskan jual beli perhiasan emas dengan perak secara ansuran atas dasar kelonggaran demi keperluan masyarakat terhadapnya ${ }^{45}$ Keharusan jual beli barang perhiasan daripada emas dan perak secara ansuran ini turut disokong oleh 'Abbās Muhammad al-Bāz. Beliau menyatakan bahawa berdasarkan hakikat yang berlaku dalam kehidupan seharian, pendapat yang sahih ialah emas dan perak tidak lagi menjadi harga kepada barangan mengikut 'urf dan amalan semasa, meskipun ia masih bernilai dan menjadi kebanggaan. Masyarakat tidak lagi menganggapnya sebagai harga barangan sebagaimana zaman terdahulu. Sebaliknya 'urf menganggapnya sebagai barangan perhiasan dan perdagangan. ${ }^{46}$

Setelah meneliti hujah-hujah yang dikemukakan oleh keduadua pandangan berhubung kedudukan jual beli barang perhiasan daripada emas ataupun perak secara ansuran, penulis berpandangan

\footnotetext{
42 Ibn Taymiyyah, Tafsīr Āyāt Ashkalāt, 622.

43 Ibn Taymiyyah, Tafsīr Āyāt Ashkalāt, 624.

44 Ibn Taymiyyah, Tafsīr Āyāt Ashkalāt, 625.

45 Yahyōa bin Sharf Abū Zakariyyā al-Nawawī, al-Majmū' Sharh alMuhadhdhab (Jeddah: Maktabah al-Irshād ,1970), 21.

46 'Abbās Aḥmad Muḥammad al-Bāz, Ahkām Ṣarf al-Nuqūd wa al'Umulāt fì al-Fiqh al Islāmī (al-Urdun: Dār al-Nafā'is, 1999), 178.
} 
bahawa pandangan kedua adalah lebih räjih̆ dan lebih tepat kerana kekuatan hujah mereka berbanding dengan hujah pandangan pertama. Ini kerana pandangan pertama lebih terikat dengan maksud zahir hadis yang melarang pertukaran barang ribawi seperti emas dan perak melainkan jika syarat persamaan kadar dan serahan segera dipenuhi. Malah, pandangan mereka dalam isu ini terutama mazhab Maliki, Shafii dan Hanbali agak bertentangan dengan pandangan mereka tentang 'illah riba . Ini kerana mereka menyatakan illah riba adalah al-thamaniyyah iaitu matawang. Tetapi bila melibatkan jual beli barang perhiasan emas atau perak secara ansuran, mereka melarangnya pula sedangkan secara realitinya baik pada zaman dahulu atau zaman sekarang, barang perhiasan emas dan perak bukan dijadikan sebagai matawang malah ia menjadi barang dagangan seperti barang-barang lain juga. Ini jelas daripada apa yang disebut oleh Abū Jayyib ${ }^{47}$ bahawa pada zaman Rasulullah SAW, para wanita telah memakai barangan perhiasan dan mereka menyedekahkan barang perhiasan tersebut kepada fakir miskin apabila tiba hari raya. Kemudian fakir miskin tersebut menjualnya kepada orang lain dengan harga yang lebih tinggi kerana mereka memerlukan wang. Sistem jual beli ini dilakukan oleh mereka walaupun mereka lebih faqīh dalam urusan agama. Justeru, berdasarkan kisah ini, barang perhiasan dijadikan sebagai barang dagangan dari dahulu lagi dan bukannya sebagai alat pertukaran atau matawang.

Selain daripada itu, pandangan kedua lebih realistik dan menepati 'urf semasa di mana masyarakat tidak menganggapnya sebagai matawang. Sebaliknya masyarakat menganggapnya sebagai barangan perhiasan yang boleh diperdagangkan seperti barang-barang perdagangan yang lain.

Sa 'id̄̄, Abū Jayyib, Bay ' al-Hullì fì al-Sharī'ah (Bayrūt: Dār al-Fikr, 1994), 17. 


\section{ANALISIS DATA}

Kajian ini adalah bertujuan untuk mengetahui sejauhmana kefahaman masyarakat wanita Islam Kg. Manjoi terhadap hukum jual beli barang perhiasan daripada emas secara ansuran. Kajian ini akan menghuraikan persoalan-persoalan berikut: Sejauhmana masyarakat memahami hukum jual beli barang perhiasan daripada emas secara ansuran? Adakah terdapat hubungan antara pemahaman masyarakat Islam Kg. Manjoi terhadap hukum jual beli barang perhiasan daripada emas dengan tahap pendidikan dan aliran pendidikan? Berdasarkan persoalan-persoalan berikut, hipotesis awal kajian telah dibuat iaitu: Pemahaman masyarakat Islam terhadap hukum jual beli barang perhiasan daripada emas secara ansuran berada di tahap yang rendah dan terdapat hubungan antara kefahaman masyarakat terhadap hukum jual beli barang perhiasan daripada emas secara ansuran dengan taraf pendidikan dan aliran pendidikan.

Data berkaitan dengan demografi responden dan keterlibatan responden terhadap jual beli barang perhiasan dianalisis secara descriptive iaitu hanya melibatkan peratusan dan kekerapan manakala data yang melibatkan kefahaman wanita Islam $\mathrm{Kg}$. Manjoi mengenai barangan ribawi dan hukum jual beli barang perhiasan daripada emas secara ansuran dianalisis secara descriptive statistics iaitu melibatkan peratusan, kekerapan dan purata atau min setiap item.

\section{Demografi Sampel}

Carta 1: Umur Responden

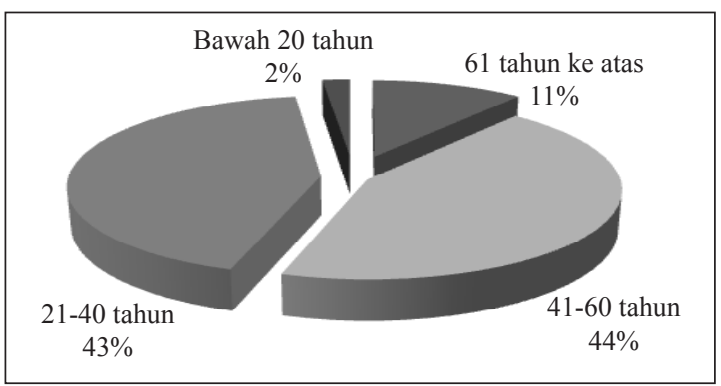

Sumber: Soal Selidik 
Pemahaman Wanita Islam Kg. Manjoi, Perak Terhadap Hukum Jual Beli Barang Perhiasan Daripada Emas Secara Ansuran

Carta 2: Status Perkahwinan

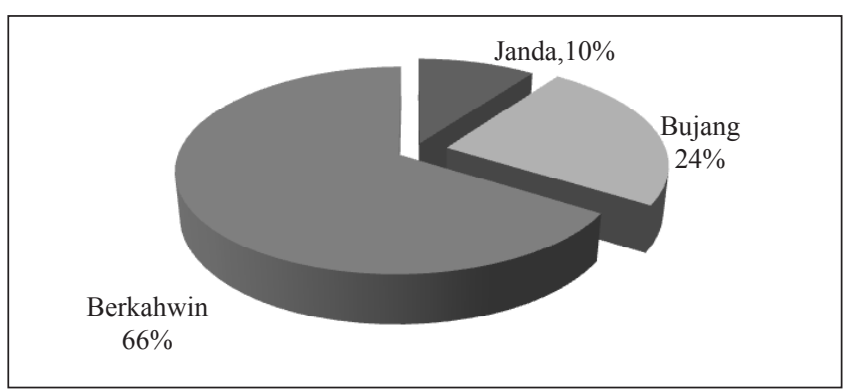

Sumber: Soal Selidik

Carta 3: Aliran Pendidikan

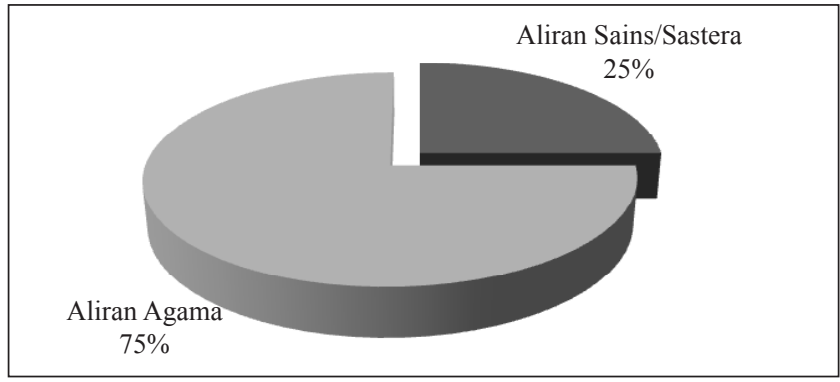

Sumber: Soal Selidik

\section{Carta 4: Tahap Pendidikan}

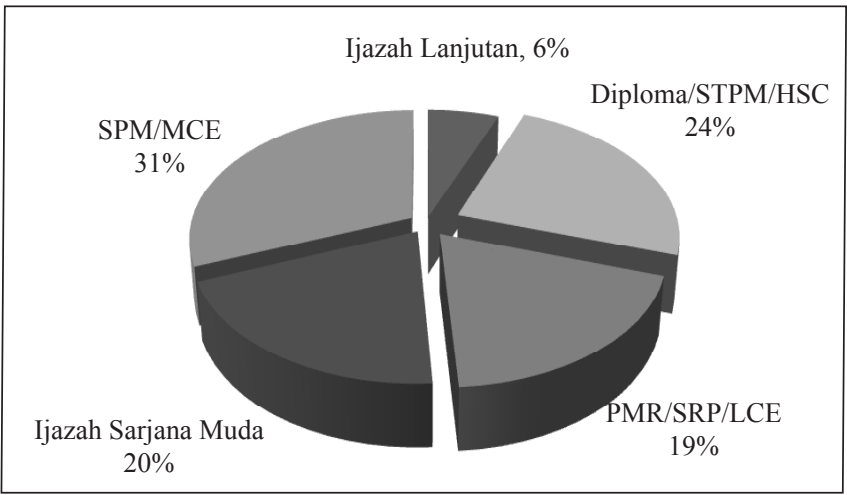

Sumber: Soal Selidik 
Carta 1 menunjukkan taburan responden mengikut peringkat umur masing-masing. Bilangan responden tertinggi berada antara umur 41 hingga 60 tahun yang mewakili 44\%, dan bilangan responden terkecil adalah berumur bawah 20 tahun iaitu seramai 2 orang yang mewakili $2 \%$. Carta 2 pula menunjukkan taburan responden mengikut status perkahwinan masing-masing. Responden yang telah berkahwin adalah paling ramai terlibat dengan jual beli barang perhiasan daripada emas berbanding dengan responden yang berstatus janda. Carta 3 menunjukkan taburan responden mengikut aliran pendidikan masing-masing. Majoriti responden belajar dalam aliran agama iaitu seramai 60 orang yang mewakili $75 \%$ berbanding responden yang belajar dalam aliran sains dan sastera dengan kadar 25\%. Daripada carta 3 , jelas menunjukkan majoriti responden mengambil aliran agama. Manakala carta 4 pula menunjukkan taburan responden mengikut tahap pendidikan masing-masing. Responden yang berpendidikan sehingga SPM merupakan bilangan yang tertinggi iaitu seramai 25 orang dengan peratusan sebanyak $31 \%$.

\section{Keterlibatan Responden Dengan Jual Beli Barang Perhiasan Daripada Emas}

Jadual 1: Pemakaian Barang Perhiasan

\begin{tabular}{|c|c|c|}
\hline & Bilangan & Peratus (\%) \\
\hline Ya & 80 & 100.0 \\
Tidak & 0 & 0.00 \\
\hline
\end{tabular}

Sumber: Soal Selidik

Jadual 1 merupakan analisis tentang keterlibatan responden dengan pemakaian barang perhiasan daripada emas. Bilangan responden yang memakai barang perhiasan daripada emas adalah 80 orang dengan mewakili $100 \%$. Melalui jadual 1, jelas menunjukkan bahawa kesemua responden memakai barang perhiasan daripada emas walaupun berbeza jenis dan bentuknya. 
Pemahaman Wanita Islam Kg. Manjoi, Perak Terhadap Hukum Jual Beli Barang Perhiasan Daripada Emas Secara Ansuran

Carta 5: Sebab Memakai Dan Membeli Barang Perhiasan

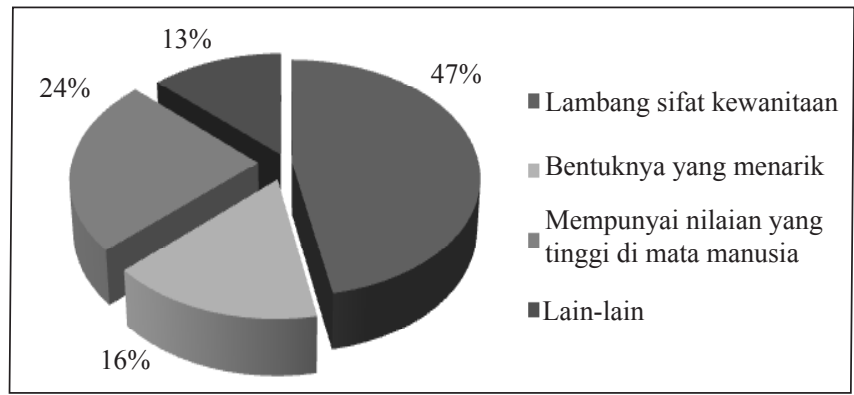

Sumber: Soal Selidik

Carta 6: Kaedah Pembelian

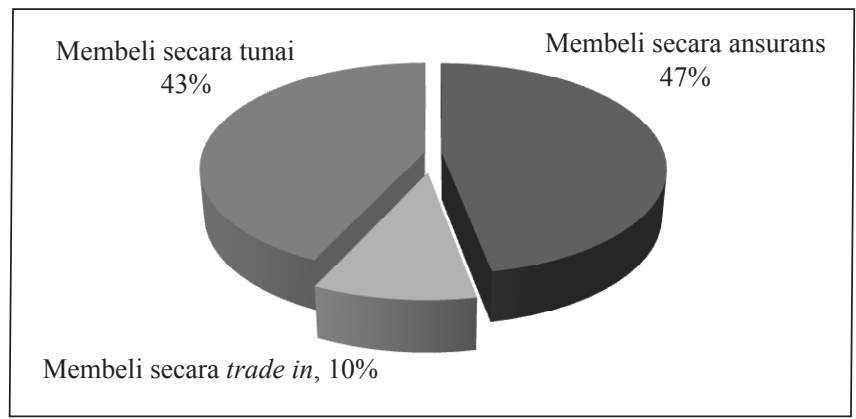

Sumber: Soal Selidik

Carta 5 menunjukkan sebab-sebab responden memakai barang perhiasan daripada emas. Terdapat seramai 38 responden yang mewakili $47 \%$ memakai barang perhiasan daripada emas disebabkan ia merupakan lambang kepada sifat kewanitaan. Responden yang memakai barang perhiasan daripada emas disebabkan faktor-faktor lain seperti suka-suka, simpanan dan untuk pelaburan adalah jumlah yang terendah dengan mewakili $13 \%$. Carta 6 pula menunjukkan kaedah pembelian yang dilakukan oleh responden dalam mendapatkan barangan perhiasan daripada emas. Kaedah pembelian secara ansuran menjadi pilihan responden apabila kaedah ini memiliki peratusan yang tertinggi berbanding kaedah yang lain. 
Jadual 2: Faktor-Faktor Pembelian Barang Perhiasan Daripada Emas Secara Ansuran

\begin{tabular}{|c|c|c|c|c|}
\hline$\frac{\nwarrow}{\frac{1}{d}}$ & $\begin{array}{l}\text { 1. Membeli } \\
\text { barang } \\
\text { perhiasan } \\
\text { secara ansuran } \\
\text { kerana tidak } \\
\text { mempunyai } \\
\text { wang yang } \\
\text { mencukupi } \\
\text { untuk } \\
\text { membelinya } \\
\text { secara tunai. }\end{array}$ & $\begin{array}{l}\text { 2. Membeli } \\
\text { barang } \\
\text { perhiasan } \\
\text { secara ansuran } \\
\text { kerana } \\
\text { yakin boleh } \\
\text { membayarnya } \\
\text { setiap bulan } \\
\text { dengan } \\
\text { jumlah yang } \\
\text { minimum. }\end{array}$ & $\begin{array}{l}\text { 3. Membeli } \\
\text { barang } \\
\text { perhiasan } \\
\text { secara ansuran } \\
\text { kerana } \\
\text { mengikut trend } \\
\text { masyarakat } \\
\text { sekarang yang } \\
\text { membelinya } \\
\text { secara } \\
\text { ansuran. }\end{array}$ & $\begin{array}{l}\text { 4. Membeli } \\
\text { barang } \\
\text { perhiasan } \\
\text { secara ansuran } \\
\text { kerana } \\
\text { mempunyai } \\
\text { kepercayaan } \\
\text { yang tinggi } \\
\text { terhadap } \\
\text { peniaganya. }\end{array}$ \\
\hline $\begin{array}{c}\text { SANGAT } \\
\text { TIDAK } \\
\text { SETUJU }\end{array}$ & $\begin{array}{c}11 \\
(13.8)\end{array}$ & $\begin{array}{c}11 \\
(13.8)\end{array}$ & $\begin{array}{c}15 \\
(18.75)\end{array}$ & $\begin{array}{c}12 \\
(15.0)\end{array}$ \\
\hline $\begin{array}{c}\text { TIDAK } \\
\text { SETUJU }\end{array}$ & $\begin{array}{c}7 \\
(8.8)\end{array}$ & $\begin{array}{c}6 \\
(7.5)\end{array}$ & $\begin{array}{c}15 \\
(18.75)\end{array}$ & $\begin{array}{c}8 \\
10.0)\end{array}$ \\
\hline $\begin{array}{l}\text { TIDAK } \\
\text { PASTI }\end{array}$ & $\begin{array}{c}14 \\
(17.5)\end{array}$ & $\begin{array}{c}18 \\
(22.5) \\
\end{array}$ & $\begin{array}{c}18 \\
(22.5) \\
\end{array}$ & $\begin{array}{c}20 \\
(25.0) \\
\end{array}$ \\
\hline SETUJU & $\begin{array}{c}18 \\
(22.5)\end{array}$ & $\begin{array}{c}24 \\
(30.0)\end{array}$ & $\begin{array}{c}14 \\
(17.5)\end{array}$ & $\begin{array}{c}19 \\
(23.8)\end{array}$ \\
\hline $\begin{array}{l}\text { SANGAT } \\
\text { SETUJU }\end{array}$ & $\begin{array}{c}30 \\
(37.4)\end{array}$ & $\begin{array}{c}21 \\
(26.2)\end{array}$ & $\begin{array}{c}18 \\
(22.5)\end{array}$ & $\begin{array}{c}21 \\
(26.2)\end{array}$ \\
\hline JUMLAH & $\begin{array}{c}80 \\
(100)\end{array}$ & $\begin{array}{c}80 \\
(100)\end{array}$ & $\begin{array}{c}80 \\
(100)\end{array}$ & $\begin{array}{c}80 \\
(100)\end{array}$ \\
\hline $\begin{array}{c}\text { NILAI } \\
\text { MIN }\end{array}$ & 3.61 & 3.48 & 3.063 & 3.363 \\
\hline
\end{tabular}

\section{Sumber : Soal selidik}

Nota : Angka tanpa kurungan menunjukkan bilangan responden. Angka dalam kurungan menunjukkan nilai peratusan.

Jadual 2 menunjukkan taburan responden mengikut bilangan, peratusan dan min berkenaan dengan faktor pembelian barang perhiasan daripada emas secara ansuran. Berdasarkan item 1 , peratus responden yang menyatakan sangat setuju dengan kenyataan ini ialah $37.4 \%$ dengan jumlah seramai 30 orang dan seramai 11 orang memilih jawapan sangat tidak setuju dengan $13.8 \%$. Bagi item 2, seramai 45 responden yang bersetuju dan sangat setuju.

Seterusnya bagi item 3, terdapat sebahagian responden yang bersetuju dengan faktor tersebut dan terdapat juga sebahagian 
responden yang tidak bersetuju dengannya. Namun terdapat juga segelintir responden yang masih dalam kekeliruan sama ada mahu memilih setuju atau tidak. Mereka memilih jawapan tidak pasti bagi kenyataan ini dengan bilangan seramai 18 orang.

Sementara bagi item 4 pula, 40 orang responden bersetuju dan sangat bersetuju dengan kenyataan ini dengan peratusan masingmasing ialah $23.8 \%$ dan $26.2 \%$. Keputusan ini menunjukkan kepercayaan yang tinggi kepada perniaga barang perhiasan daripada emas juga merupakan faktor pembelian secara ansuran dilakukan.

\section{Tahap Kefahaman Responden Terhadap Hukum Jual Beli Barang Perhiasan Daripada Emas Secara Ansuran}

Bagi mewujudkan tahap kefahaman terhadap hukum jual beli barang perhiasan secara ansuran dalam kalangan responden, bahagian D dalam borang soal selidik telah digunakan untuk kajian ini yang mengandungi 7 soalan. Taburan skor seperti berikut diambil sebagai skala: kurang daripada $50 \%$ bermakna pemahaman yang rendah dan 50\%-75\% dan lebih daripada $75 \%$ bermakna mempunyai pemahaman yang sederhana dan tinggi mengikut persetujuan responden terhadap setiap kenyataan.

Carta 7: Hukum Jual Beli Barang Perhiasan Yang Diperbuat Daripada Emas Secara Ansurans

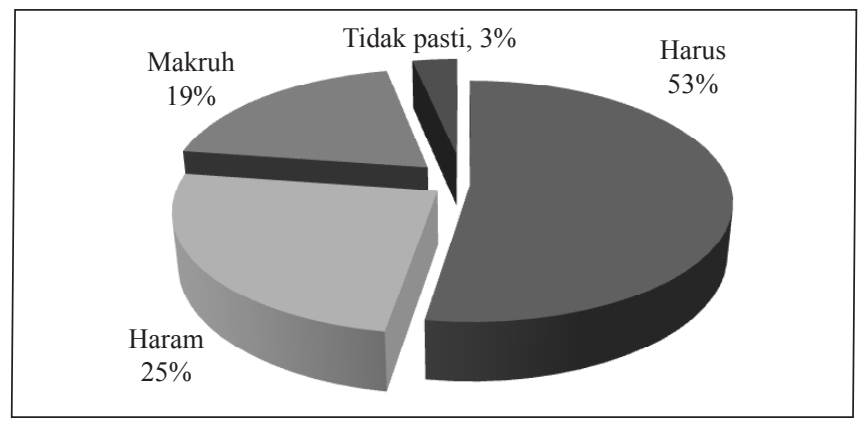

Sumber: Soal Selidik 
Merujuk kepada carta 7, seramai 52 orang yang memilih jawapan tidak pasti dengan peratusan sebanyak $65 \%$.

\section{Jadual 3:Kefahaman Responden Terhadap Kenyataan Berkaitan Hukum Jual Beli Barang Perhiasan Daripada Emas Secara Ansuran}

\begin{tabular}{|c|c|c|c|c|c|c|}
\hline$\vec{\oplus}$ & PERKARA & 飠名 & 䆖畐 & 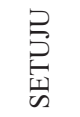 & 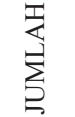 & 变文 \\
\hline 1 & $\begin{array}{l}\text { Terdapat perselisihan pendapat } \\
\text { dalam kalangan ulama terhadap } \\
\text { jual beli barang perhiasan } \\
\text { daripada emas secara ansuran. }\end{array}$ & $\begin{array}{c}5 \\
(6.2)\end{array}$ & $\begin{array}{c}57 \\
(71.2)\end{array}$ & $\begin{array}{c}18 \\
(22.6)\end{array}$ & $\begin{array}{c}80 \\
(100)\end{array}$ & 3.213 \\
\hline 2 & $\begin{array}{l}\text { Terdapat ulama yang } \\
\text { mengharuskan jual beli barang } \\
\text { perhiasan daripada secara } \\
\text { ansuran. }\end{array}$ & $\begin{array}{c}8 \\
(10.0)\end{array}$ & $\begin{array}{c}45 \\
(56.3)\end{array}$ & $\begin{array}{c}27 \\
(33.7)\end{array}$ & $\begin{array}{c}80 \\
(100)\end{array}$ & 3.35 \\
\hline 3 & $\begin{array}{l}\text { Terdapat sebahagian ulama } \\
\text { yang tidak mengharuskan jual } \\
\text { beli barang perhiasan daripada } \\
\text { emas secara ansuran. }\end{array}$ & $\begin{array}{c}4 \\
(5.0)\end{array}$ & $\begin{array}{c}48 \\
(60.0)\end{array}$ & $\begin{array}{c}28 \\
(35.0)\end{array}$ & $\begin{array}{c}80 \\
(100)\end{array}$ & 3.388 \\
\hline 4 & $\begin{array}{l}\text { Keharusan jual beli barang } \\
\text { perhiasan daripada emas secara } \\
\text { ansuran adalah disebabkan } \\
\text { emas bertukar menjadi barang } \\
\text { dagangan apabila telah menjadi } \\
\text { barang perhiasan. }\end{array}$ & $\begin{array}{c}7 \\
(8.8)\end{array}$ & $\begin{array}{c}54 \\
(67.5)\end{array}$ & $\begin{array}{c}19 \\
(23.7)\end{array}$ & $\begin{array}{c}80 \\
(100)\end{array}$ & 3.188 \\
\hline 5 & $\begin{array}{l}\text { Penangguhandalampembayaran } \\
\text { jual beli barang perhiasan yang } \\
\text { diperbuat daripada emas tidak } \\
\text { membawa kepada riba. }\end{array}$ & $\begin{array}{c}7 \\
(8.8)\end{array}$ & $\begin{array}{c}49 \\
(61.2)\end{array}$ & $\begin{array}{c}24 \\
(30.0)\end{array}$ & $\begin{array}{c}80 \\
(100)\end{array}$ & 3.275 \\
\hline 6 & $\begin{array}{l}\text { Perhiasan emas telah terkeluar } \\
\text { dari kategori emas yang belum } \\
\text { dibentuk. }\end{array}$ & $\begin{array}{c}8 \\
(10.0)\end{array}$ & $\begin{array}{c}58 \\
(72.5)\end{array}$ & $\begin{array}{c}14 \\
(17.5)\end{array}$ & $\begin{array}{c}80 \\
(100)\end{array}$ & 3.075 \\
\hline
\end{tabular}


Pemahaman Wanita Islam Kg. Manjoi, Perak Terhadap Hukum Jual Beli Barang Perhiasan Daripada Emas Secara Ansuran

\begin{tabular}{|l|l|c|c|c|c|c|}
\hline 7 & $\begin{array}{l}\text { Barang perhiasan daripada } \\
\text { emas tidak dianggap sebagai } \\
\text { barang ribawi kerana sudah } \\
\text { diubah bentuk dan tidak kekal } \\
\text { sifat asalnya. }\end{array}$ & $\begin{array}{l}\text { (12.5) } \\
\text { (78.7) }\end{array}$ & $\begin{array}{c}7 \\
(8.8)\end{array}$ & $\begin{array}{c}\text { (100) } \\
\text { (10) }\end{array}$ & 2.963 \\
\hline
\end{tabular}

Sumber : Soal Selidik

Nota : Angka tanpa kurungan menunjukkan bilangan responden

Angka dalam kurungan menunjukkan nilai peratusan

Jadual 3 menunjukkan taburan responden mengikut bilangan, peratusan dan min berkenaan dengan kefahaman responden terhadap item-item yang dinyatakan. Bagi item 1, 22.6\% responden bersetuju dengan kenyataan ini. Bagi item 2, hanya $33.7 \%$ responden yang bersetuju dengan kenyataan ini. Bagi item 3, seramai 28 orang responden yang setuju dengan 35\% dan sebanyak $23.7 \%$ responden bersetuju bagi item 4 . Bagi item 5 dan $6,30 \%$ dan $17.5 \%$ responden yang bersetuju dengan kenyataan ini. Bagi item 7, 8.8\% responden bersetuju dengan kenyataan ini.

Berdasarkan kenyataan-kenyataan ini, bilangan responden yang bersetuju adalah kurang daripada 50\%. Ini jelas menunjukkan kefahaman responden terhadap kenyataan ini berada di tahap yang rendah.

\section{Hubungan Antara Aliran Pendidikan Dan Tahap Pendidikan Dengan Mengetahui Hukum Jual Beli Barang Perhiasan Secara Ansuran}

Jadual 4 : Hubungan Antara Aliran Pendidikan Dengan Mengetahui Hukum Jual Beli Barang Perhiasan Daripada Emas Secara Ansuran

\begin{tabular}{|c|c|c|c|}
\hline & & $\begin{array}{c}\text { Aliran } \\
\text { Pendidikan }\end{array}$ & $\begin{array}{c}\text { Mengetahui } \\
\text { Hukum Jual } \\
\text { Beli Barang } \\
\text { Perhiasan } \\
\text { Daripada Emas } \\
\text { Secara Ansuran }\end{array}$ \\
\hline \multirow{3}{*}{ Aliran pendidikan } & \multirow{3}{*}{$\begin{array}{l}\text { Pearson Correlation } \\
\text { Sig. (2-tailed) } \\
\text { N }\end{array}$} & 1 & $.648^{* *}$ \\
\hline & & & .000 \\
\hline & & 80 & 80 \\
\hline
\end{tabular}

Sumber: SPSS 20.0 
Berdasarkan kepada Jadual 4, didapati nilai pekali kolerasi (Pearson Correlation) antara pembolehubah aliran pendidikan dengan pengetahuan mengenai hukum jual beli barang perhiasan daripada emas secara ansuran ialah 0.648. Ini menunjukkan bahawa hubungan antara kedua-dua pembolehubah berada pada tahap sederhana. Nilai signifikan antara kedua-dua pembolehubah ini ialah 0.000. Melalui nilai ini, dapatlah dilihat bahawa wujud hubungan yang signifikan di antara kedua-dua pembolehubah kerana nilainya tidak melebihi aras signifikan yang ditetapkan iaitu 0.01. Kesimpulannya, aliran pendidikan mempengaruhi pemahaman responden berkenaan dengan pengetahuan mengenai hukum jual beli barang perhiasan daripada emas secara ansuran.

Jadual 4: Hubungan Antara Tahap Pendidikan Dengan Mengetahui Hukum Jual Beli Barang Perhiasan Daripada Emas Secara Ansuran

\begin{tabular}{|c|c|c|c|}
\hline & & $\begin{array}{c}\text { Tahap } \\
\text { Pendidikan }\end{array}$ & $\begin{array}{l}\text { Hukum } \\
\text { Jual Beli }\end{array}$ \\
\hline \multirow{3}{*}{ Tahap Pendidikan } & \multirow{3}{*}{$\begin{array}{l}\text { Pearson Correlation } \\
\text { Sig. (2-tailed) } \\
\text { N }\end{array}$} & 1 & $.680^{* *}$ \\
\hline & & & .000 \\
\hline & & 80 & 80 \\
\hline
\end{tabular}

Sumber: SPSS 20.0

Jadual 5 menunjukkan terdapat hubungan yang sederhana antara tahap pendidikan dengan pembolehubah hukum jual beli barang perhiasan daripada emas secara ansuran dengan nilai pekali kolerasinya 0.680 . Nilai signifikan bagi kedua-dua pembolehubah ini ialah 0.000. Ianya adalah signifikan disebabkan nilainya tidak melebihi aras signifikan yang ditetapkan iaitu 0.01. Dari Jadual 5, jelas menunjukkan tahap pendidikan mempengaruhi pengetahuan responden terhadap hukum jual beli barang perhiasan daripada emas secara ansuran.

Kesimpulannya, kajian ini mendapati majoriti responden mempunyai tahap kefahaman yang rendah tentang hukum jual beli barang perhiasan daripada emas di mana kurang 50\% responden yang memberikan jawapan setuju kepada item yang dikemukakan dan wujud hubungan antara kefahaman terhadap jual beli barang perhiasan secara ansuran dengan tahap pendidikan dan aliran pendidikan. 
Pemahaman Wanita Islam Kg. Manjoi, Perak Terhadap Hukum Jual Beli Barang Perhiasan Daripada Emas Secara Ansuran

\section{RUMUSAN}

Hasil daripada kajian mendapati hukum jual beli barang perhiasan daripada emas secara ansuran menggunakan wang kertas adalah harus. Ini kerana barang perhiasan yang diperbuat daripada emas telah terkeluar daripada kategori barang ribawī. Barang perhiasan daripada emas dianggap sebagai barang dagangan dan tidak tertakluk dengan syarat jual beli barang ribawī.

Daripada kajian juga didapati keseluruhan responden telah melibatkan diri dengan jual beli barang perhiasan daripada emas. Kajian juga menunjukkan bahawa aliran dan tahap pendidikan mempengaruhi pengetahuan responden terhadap hukum jual beli barang perhiasan daripada emas secara ansuran. Berhubung kefahaman wanita Islam $\mathrm{Kg}$. Manjoi terhadap hukum jual beli barang perhiasan daripada emas secara ansuran, didapati kefahaman mereka berada di tahap yang rendah. Hal ini mungkin disebabkan mereka tidak banyak terdedah dengan isu-isu berkaitan muamalat Islam baik melalui pendidikan rasmi atau tidak rasmi.

\section{BIBLIOGRAFI}

Al-Balādharī, Abū 'Abbās Aḥmad bin Yaḥyā. Futūḥ al-Buldān. Bayrūt: Mu'assasah al-Ma'ārif, 1987.

Al-Barr, Abū 'Umar Yūsuf bin 'Abd Allah. Istidhkār. Jil. 19, Bayrūt: Dār Qutaybah, 1993.

Al-Bāz, 'Abbās Aḥmad Muḥammad. Aḥkām Șarf al-Nuqūd wa al- 'Umulāt fì al-Fiqh al Islāmī. Al-Urdun: Dār al-Nafā'is, 1999.

Al-Dusūqī, Muhammad 'Urfah. Hēāshiyah al-Dusūqī 'alā Sharh al-Kabīr. Jil. 3. Al-Miṣr: Maktabah 'Isā al-Bābī al-Halabī wa Shurakah, 1809.

Al-Ḥumaydī, Muḥammad bin Futūḥ. Al-Jam ' Bayn al-Ṣahịhayn. Jil. 2, Al-Su'ūdiyyah: Dār Ibn Hazm, t. t.

Al-Kāsānī, 'Alā' al-Dīn Abū Bakr. Badā'i ' al-Șanā 'i ' fì Tartīb alSharā'í. Jil. 5. Bayrūt: Dār al-Kutub al-'Ilmiyyah, 1986. 
Al-Mișrī, Rafīq Yūnus. Al-Jām' fì Ușūl al-Ribā. Damshiq: Dār al-Qalam, 2001.

Al-Mun'im, Maḥmūd 'Abd al-Raḥman. Mu 'jam al-Muștalahăt wa al-Alfāz al-Fiqhiyyah. Jil. 1. Al-Qāhirah: Dār al-Faḍilah, 1999.

Al-Nawawī, Yaḥyā bin Sharif Abū Zakariyyā. Al-Majmū' Sharh al-Muhadhdhab. Jil. 9. Al-Su'ūdiyyah: Maktabah al-Irshād, 1970.

Al-Qalyūbī, Aḥmad bin Aḥmad. Hāashiyah al-Qalayūbī 'alā Kanz al-Rāghib. Bayrūt: Dār al-Kutub al-'Ilmiyyah, 1998.

Al-Qaraḍāwī, Yūsuf. Dirāsah fì Maqāṣid al-Sharī'ah. Al-Qāhirah: Dār al-Shurūq, 2008.

Al-Qaraḍāwī, Yūsuf. Fiqh al-Zakāh. Jil. 1. Bayrūt: Mu'assasah al-Risālah, 1973.

Al-Sarakhsī, Abū Bakr Muḥammad bin Aḥmad bin Abū Sahl. AlMabsūṭ. Jil. 14. Bayrūt: Dār al-Ma'rifah, 1989.

Al-Shāfi'ī, Muḥammad bin Idrīs. Al-Umm. Jil. 4. Al-Manșūrah: Dār al-Wafā', 2001.

Al-Sharbīn̄i, Shams al-Dīn Muhammad bin Aḥmad. Mughnī alMuhtāj ilā Ma'rifah Ma'ānī Alfāz al-Minhāj. Jil. 2. Bayrūt: Dār al-Fikr, 1978.

Al-Zarkashī, Abū 'Abd Allah Badr al-Dīn. Al-Ma'thūr fì alQawā'id al-Fiqhiyyah. Jil. 3. Kuwayt: Wizārah al-Awqāf wa al-Shu'ūn al-Islāmiyyah, 1985.

Azizi Yahaya et al. Menguasai Penyelidikan Dalam Pendidikan: Teori, Analisis Dan Interpretasi Data. Kuala Lumpur: PTS Profesional Publishing Sdn Bhd., 2006.

Ibn 'Ābidīn, Muḥammad Amīn. Radd al-Muhtār 'alā al-Durr al-Mukhtār Sharh Tanwīr al- Abṣār. Jil. 7. Al-Riyāḍ: Dār 'Ālim al-Kutub, 2003. 
Pemahaman Wanita Islam Kg. Manjoi, Perak Terhadap Hukum Jual Beli Barang Perhiasan Daripada Emas Secara Ansuran

Ibn al-Qayyim, Shams al-Dīn Abū 'Abd Allah. I'lām alMuwaqqi'īn 'an Rabb al-'Ālamīn. Jil. 2. Al-Su'ūdiyyah: Dār Ibn Jawzy, 2002.

Ibn Anas, Mālik. Al-Mudawwanah al-Kubrā. Jil. 8. Bayrūt: Dār al-Kutub al-'Ilmiyyah, 1902.

Ibn Anas, Mālik. Al-Muwatțā'. Jil. 3. t. t.: Majmū'ah al-Furqān al-Tijāriyyah, 2003.

Ibn Hubayrah,Yahyā bin Muhammad. Ifșāḥ 'an Ma 'ānī al-Ṣahāḥ. Jil. 1. Al-Riyāḍ: Dār al-Wațan, 1996.

Ibn Manz̄ūr, Muhammad bin Mukarram. Lisān al-'Arab. Jil. 4. Al-Qāhirah: Dār al-Ma‘ārif, 1119.

Ibn Mufliḥ, Isḥāq Burhān al-Dīn Ibrāhīm. Mubdi 'Sharḥ alMuqni '. Jil. 4. Bayrūt: Dār al-Kutub 'Ilmiyyah, 1997.

Ibn Mundhir, Abū Bakr Muḥammad bin Ibrāhīm. Ijmāa'. Ajmān: Dār al-Furqān, 1999.

Ibn Qudāmah, Ābu Muḥammad 'Abd Allah bin Aḥmad. AlMughnī. Jil. 6. Al-Riyāẹ: Dār Ā'lam al-Kutub, 1985.

Ibn Rushd al-Qurțubī. Al-Bayān wa al-Tahṣīl. Jil. 6. Bayrūt: Dār al-Gharbī al-Islāmī,1988.

Ibn Rushd al-Qurțubī, Bidāyah al-Mujtahid wa Nihāyah alMuqtașid. Jil. 2. Bayrūt: Dār al-Ma'rifah, 1982.

Ibn Taymiyyah, Abū al-'Abbās Aḥmad bin 'Abd al-Ḥalīm alHarrānī, Majmū' al-Fatāwā. Jil. 29. Al-Manșūrah: Dār alWafā', 2005.

Ibn Taymiyyah, Abū al-'Abbās Aḥmad bin 'Abd al-Ḥalim alḤarrān̄i. Al-Akhbār al-'Ilmiyyah al-Ikhtiyārāt al-Fiqhiyyah . t. t.: Dār 'Āṣimah, 1950.

Ibn Taymiyyah, Aḥmad bin 'Abd al-Halīm. Tafsīr Āyāt Ashkalat. Jil. 1. Al-Riyāḍ: Maktabah al-Rushd, 1996.

Majma“ al-Fiqh al-Islāmī al-Duwalī. http://www.fiqhacademy. org.sa/qrarat/3-9.htm, diakses pada 30 April 2012 . 
Mat Noor Mat Zain. "Jual Beli Barangan Kemas Daripada Emas Dan Perak: Reaksi Terhadap Pandangan Ibn Taimiyyah". Kertas Persidangan Seminar Penjanaan Ekonomi Melalui Transaksi Wang Dinar 2009.

Muhammad bin Șālih al-'Uthaymīn et al. Fatāwā al-Buyū'wa alMuāmalāt al-Māliyyah. Iskandariyyah: Dār al-Imān, 2004.

Muslim, Abū al-Ḥusayn Muslim. Șahīh Muslim. Al-Riyāạ: Bayt al-Afkār al-Dawliyyah, 1998.

Noraini Idris. Penyelidikan Dalam Pendidikan. Kuala Lumpur: Mc Graw Hill, 2010.

Noresah Baharom et al. Kamus Dewan Edisi Keempat. Kuala Lumpur: Dewan Bahasa Dan Pustaka, 2007.

Sa 'idī, Abū Jayyib. Bay 'al-Huliy fì al-Sharī'ah. Bayrūt: Dār alFikr, 1994.

Zaharuddin Abd. Rahman. Riba Dan Isu Kewangan Semasa. Kuala Lumpur: Telaga Biru, 2010. 